\title{
Cadmium Bioremediation Potential of Bacillus sp. and Cupriavidus sp.
}

\author{
Sneh Lata ${ }^{1}$ (D) Tulika Mishra ${ }^{2}$ and Sukhminderjit Kaur ${ }^{1 *}$ (D) \\ ${ }^{1}$ University Institute of Biotechnology, Chandigarh University, Gharuan - 140 413, Punjab India. \\ ${ }^{2}$ American University School of Medicine, Aruba, Suwanee, GA 30024, USA.
}

\begin{abstract}
Heavy metals are extremely toxic and their presence in the environment is a known risk factor. Out of them, cadmium is known for its fatal effects on the environment, humans and soil. Bioremediation offers an economical solution for detoxifying such metals. So, the present study aimed to isolate Bacillus sp. and Cupriavidus sp. from the cadmium contaminated soils and studied their cadmium bioremediation potential. Strains that have exhibited good tolerance upto $1000 \mathrm{ppm}$ and $1500 \mathrm{ppm}$ of cadmium concentration and good absorption to cadmium were studied by scanning electron microscopy. An increase in the size of the bacterial cells was observed. The absorption of cadmium by bacterial cells was further confirmed by atomic absorption spectroscopy and found that the sorption rate of Bacillus sp. ECd004 was $87 \%$ and of Cupriavidus sp. SCd005 was $90 \%$. Furthermore, these strains were exposed to cadmium contaminated soil in the form of bioformulations and their role in the rate of seed germination of Vigna radiata and Cicer aertinum and impact on seedlings growth was determined. Seed germination and growth rate was found to be double in comparison to the negative control. This investigation proves their efficacy to use in highly cadmium contaminated soils making them a suitable choice for bioremediation.
\end{abstract}

Keywords: Bioremediation, SEM, AAS, Absorption, Bioformulation

*Correspondence: sukhminderjit.uibt@cumail.in; +91 9815509366

(Received: June 07, 2021; accepted: August 25, 2021)

Citation: Lata S, Mishra T, Kaur S. Cadmium Bioremediation Potential of Bacillus sp. and Cupriavidus sp. J Pure Appl Microbiol. 2021;15(3):1665-1680. doi: 10.22207/JPAM.15.3.63

(C) The Author(s) 2021. Open Access. This article is distributed under the terms of the Creative Commons Attribution 4.0 International License which permits unrestricted use, sharing, distribution, and reproduction in any medium, provided you give appropriate credit to the original author(s) and the source, provide a link to the Creative Commons license, and indicate if changes were made. 


\section{INTRODUCTION}

Industrial rebellion has expedited the ecosystem pollution exorbitantly due to the discharge of toxic heavy metals. Cadmium is one of the most toxic heavy metal which has entered in aquatic streams, rivers, ponds through industrial operations such as electroplating, smelting, manufacturing of batteries etc. Many agricultural practices such as use of pesticides, phosphate fertilizers, sewage sludge etc. also supplement the remarkable amounts of cadmium in soil. Toxicity of cadmium is a well-known risk factor. Accumulation of cadmium leads to reproductive system failure, brain damage, and kidney damage to human beings ${ }^{1}$. Renal damage was also reported due to cadmium toxicity ${ }^{2}$. International Agency for Research on Cancer (IARC) has declared cadmium as carcinogen ${ }^{3}$. The physical methods such as soil isolation and chemical processes such as soil washing were used earlier for removing cadmium are neither cost effective nor they are feasible. Hence, there is a need to develop a cost effective and eco-friendly solution to this problem. Biological methods using microorganisms are the most promising because of their efficiency, and feasibility ${ }^{4}$. Microorganisms have developed the resistance or different ways of dealing with them such as oxidation, bioleaching and absorption. Many findings were reported for biological remediation of cadmium. Alcaligenes eutrophus $\mathrm{CH} 34$ bacterial strain was grown on a pilot plant which degraded upto $90 \%$ of the cadmium $^{5}$. Bacterial strain Rhodotorula sp. Y11 was able to degrade $11.38 \mathrm{mg} / \mathrm{g}$ of cadmium ${ }^{6}$. Recent studies revealed that Staphylococcus xylosus and Pseudomonas sp. were able to degrade $278 \mathrm{mg} / \mathrm{g}$ and $250 \mathrm{mg} / \mathrm{g}$ of cadmium respectively ${ }^{7}$. Pseudomonas aeruginosa strain KUCd1 showed its ability to remove about $75 \%$ and $89 \%$ of cadmium ${ }^{8}$. Spirogyra and Oscillatoria sp. were studied for sequestration of cadmium from industrial wastewater ${ }^{9}$. Seeds of Vigna radiata were investigated by irrigating the soil with untreated wastewater and compared with biologically treated wastewater and found that growth attributes were significantly enhanced due to treatment with biologically treated water which decreases Total dissolved solids, Total suspended solids and metal content in soil ${ }^{10}$. Lepidium sativum L. and Eruca sativa were irrigated by wastewater and found that heavy metals especially cadmium have started accumulating in their edible parts and roots ${ }^{11}$. All these reports showed that microorganisms have ability to remediate the cadmium but when exposed to industrial level, the degradation does not reach to expected limit. So, current investigation mainly focusses on the significant solution of this problem by remediating the high concentration of cadmium by bacterial cells with respect to its cadmium biosorption ability by using Scanning Electron Microscopy and Atomic Absorption Spectroscopy. Furthermore, the cadmium removal efficiency of strains was checked by treating industrial effluents and demonstrating the effects of prepared bioformulations on seed germination as well as seedling growth of Vigna radiata and Cicer aertinum.

\section{MATERIAL AND METHODS}

\section{Sample collection and analysis}

Fifty wastewater samples were collected from the various industrial cities of Punjab viz. areas of Mohali, Chandigarh, and Ludhiana. Samples from various industries such as electroplating industry, steel industry and battery manufacturing industries were collected where effluent from the industries is discharged. All the samples were tested for physicochemical parameters including biochemical oxygen demand, chemical oxygen demand, total dissolved solids, total suspended solids and chloride and determined by following the method of American Public Health Association ${ }^{12}$. The samples were tested and quantified for cadmium concentration through spectrophotometric assay as described by M.R. Ullah ${ }^{13}$ using Alizarin red S solution

Isolation and screening of cadmium resistant bacteria

The samples were employed for isolation of cadmium resistant bacteria which was done using the method of Marjan et $\mathrm{al}^{14}$. Isolation was done by serially diluting the samples and then inoculating by using spread plate technique in nutrient agar medium supplemented with cadmium chloride. The plates were incubated for $24 \mathrm{hrs}$. at $37^{\circ} \mathrm{C}$. The microorganisms which showed growth were purified further by streak plate method. The isolated stains were checked for their pollution reduction capabilities by preparing their inoculum following the method 
of Krishnaswamy et al., ${ }^{15}$ and incubating them with sterilized wastewater. Furthermore, to select potent cadmium resistant bacteria, the stains were exposed to high concentrations of cadmium ranging from $100 \mathrm{ppm}-1500 \mathrm{ppm}$.

\section{Characterization of Selected Strains}

Bacterial isolates were identified through various morphological, biochemical tests which were performed in accordance with standard methodology from Bergey's Manual ${ }^{16}$. For molecular characterization, PCR amplification was performed by Merck - Genei PCR mix by using universal primers 27F and 1495R. 16S rRNA sequencing was done by using $3730 x \mathrm{I}$ DNA Analyzer. 16S rRNA sequences were further analyzed for homology using Basic Local Alignment Search Tool and phylogenetic trees were constructed using MEGA-X software.

Study of biosorption potential using Scanning electron microscopy and AAS

SEM was performed following the method of Fischer, E.R. ${ }^{17}$. Six-hour old culture was taken, and centrifugation was done at $11,200 \mathrm{~g}$ at $4^{\circ} \mathrm{C}$ for $5 \mathrm{~min}$. Then pellet was washed in phosphate buffer for 3 times and was fixed with $0.25 \%$ glutaraldehyde solution for 1 hour. Again, washed the cells with same buffer for 3 times and centrifugation was done at $11,200 \mathrm{~g}$ at $4^{\circ} \mathrm{C}$ for 5 $\mathrm{min}$. The samples were dehydrated with acetone in series of $30-90 \%$ and finally, suspended in $100 \%$ acetone. Mounting of samples was done on the SEM stubs by using silver tape and coated with a thin layer of gold. The samples were observed at different magnifications.

Biosorption studies of bacterial cultures by AAS

Biosorption ability of bacterial isolates was determined by using Atomic Absorption Spectrometry and following the method of Khan et al. ${ }^{18}$.

\section{Cadmium Biosorption of live bacterial isolates}

The bacterial strains were grown in 100 $\mathrm{ml}$ of Nutrient broth supplemented with $2 \mathrm{ppm}$ of cadmium at optimum temperature and $\mathrm{pH}$ to determine their biosorption efficiency for 24 hrs. Control was prepared by adding $2 \mathrm{ppm}$ of cadmium without the organism. Samples $(5 \mathrm{ml})$ were withdrawn from every flask on the day 2 , day 4 , day 6 and day 8 , and centrifugation of broth was done at $1008 \mathrm{~g}$ for $5 \mathrm{~min}$. The pellets were weighed and divided into two parts, one part was digested with acid (acid digested, $0.2 \mathrm{~N} \mathrm{HNO}_{3}$ ) to release absorbed cadmium and washing of second part was done by using EDTA $(0.5 \mathrm{M})$ in order to gather cadmium adsorbed on the cell surface. Uptake values were determined and standard absorption curve was prepared to measure cadmium concentration with the help of AAS at $228.8 \mathrm{~nm}$.

\section{Removal of Cadmium by Heat inactivated bacterial cells}

To estimate the cadmium biosorption capacity of heat inactivated bacterial cells, they were inoculated on nutrient broth (HiMedia, Mumbai) and incubation was done in shaking conditions at $37^{\circ} \mathrm{C}$. After the incubation of 24 hrs., the bacterial cells were autoclaved in order to inactivate them. Centrifugation was done at $11,200 \mathrm{~g}$ for $10 \mathrm{~min}$. Cells were rinsed with deionized distilled $\mathrm{H}_{2} \mathrm{O}$ and dried out in oven at $80^{\circ} \mathrm{C}$. The bacterial cells $(0.5 \mathrm{~g})$ were added in $2 \mathrm{ppm} \mathrm{Cd}$ solution $(100 \mathrm{ml})$ and incubation was done in shaker at $37^{\circ} \mathrm{C}$ and centrifuged at $1008 \mathrm{~g}$ for $5 \mathrm{~min}$. Quantity of $\mathrm{Cd}$ was measured by using both supernatants and pellets by AAS.

\section{Cadmium removal from industrial effluent}

The ability of the bacterial isolate to reduce cadmium from industrial wastewater was also checked. The experiment was performed in three different sets in which effluents of electroplating, battery and steel industry were treated with both the strains. Distilled water and bacterial culture were taken as positive control and industrial effluents without bacterial cultures were taken as negative control. $10 \mathrm{ml}$ of samples were taken out from each flask after incubation of 2, 4, 6 and 8 days and were employed to measure the concentration of cadmium in the wastewater.

\section{Preparation of bioformulation}

Bioformulations of isolated cultures were prepared to check whether they promote and enhance the growth of the plants grown in contaminated samples. Firstly, carrier material (peat) was powdered after passing through 0.15 $\mathrm{mm}$ sieve and was neutralized to $\mathrm{pH} 7$ by using calcium carbonate. The carrier material was then packed into autoclave bags and sterilized. The inoculum was used as starter culture for growing the bacterial cells at $37^{\circ} \mathrm{C}$ for $24 \mathrm{hrs}$. to attain maximum cell population up to $10^{8} \mathrm{CFU} / \mathrm{ml}$. The inoculant packets were prepared by mixing the 
sterilized carrier material with bacterial cells. The formulations were prepared by following the method of Hasan et al. ${ }^{19} .50 \mathrm{~g}$ of carrier was mixed with $20 \mathrm{ml}$ of bacterial broth culture $\left(1.0 \times 10^{8}\right.$ cells/ $\mathrm{ml})$. The prepared bioformulation was incubated in laminar air flow for $24 \mathrm{hrs}$. and packed in polythene bags and sealed. The packets were stored in cool place till further use.

\section{Study of effect of bioformulation on Vigna radiata and Cicer arietinum}

Seeds of Vigna radiata and Cicer arietinum were chosen for the study of effect of bioformulations on seed germination rate, shoot and root length of seedlings. $20 \mathrm{~g}$ of bioformulation was mixed with $40 \mathrm{ml}$ of water (1:2 ratio, as recommended by ICAR, Goa) ${ }^{20}$. Seeds were soaked in the bioformulation for 1 hour so that a thin layer is uniformly coated on to the surface of seeds. Then, seeds were shade dried for $30 \mathrm{~min}$. prior to sowing in soils collected for the study (from contaminated sites: electroplating, steel and battery industry). The effect of bioformulations on seeds germination rate as well as on root and shoot length of seedlings was compared with positive control (garden soil) and negative control (soil without bioformulation). The experiments were performed in three sets in which seeds of $V$. radiata and $C$. aertinum were treated with formulations.

\section{RESULTS AND DISCUSSION Sample Analysis}

The range of $B O D$ values from electroplating industry samples was $31-79 \mathrm{mg} / \mathrm{l}$. Similarly, in samples from steel industry and battery industry the range for BOD was $32-99 \mathrm{mg} / \mathrm{l}$ and $31-100 \mathrm{mg} / \mathrm{I}$ respectively. The permissible limit for BOD is $35 \mathrm{mg} / \mathrm{l}$. So, industrial. samples were not in acceptable limit and can impose harmful effect on aquatic lives. COD values ranged from 250-986 $\mathrm{mg} / \mathrm{l}$ in electroplating industry samples. Battery industry samples and steel industry exhibited COD range of 240-955 mg/l and 330-990 mg/l respectively. The permissible limit for COD is 250 $\mathrm{mg} / \mathrm{l}$. The range of BOD and COD was quite high in all samples and do not comply with corporations like Food Machinery and Chemical Corporation ${ }^{21}$ and World Health Organization standard ${ }^{22}$. Total dissolved solids values ranged from 540-1305 $\mathrm{mg} / \mathrm{l}$ in electroplating industry samples and 784-2372 mg/l in steel industry samples. Battery industry samples exhibited a range of 412-2395 $\mathrm{mg} / \mathrm{l}$. TSS values ranges from $30 \mathrm{mg} / \mathrm{l}$ to $460 \mathrm{mg} / \mathrm{l}$ in electroplating industry samples and 50-899 $\mathrm{mg} / \mathrm{l}$ in steel industry samples. Battery industry samples, TSS values varied from $20-799 \mathrm{mg} / \mathrm{l}$. The difference in TDS and TSS values of samples is due to the type of contaminants and salts as well as the treatment processes which are used to achieve the permissible limits. There is direct relationship between cadmium concentration and suspended matter due to the association of particulate matter ${ }^{23}$. For chloride estimation, samples from electroplating industry exhibit the range of 120$795 \mathrm{mg} / \mathrm{l}$, steel industry samples showed the range of $25-837 \mathrm{mg} / \mathrm{l}$ whereas samples from battery were in range of 94-643 mg/l. Cadmium is extremely toxic beyond $0.7 \mathrm{mg} / \mathrm{l}$ concentration. Samples of electroplating industry were polluted with cadmium in concentration range of 1.42-3.9 $\mathrm{mg} / \mathrm{l}$. Steel industry exhibited the range of 1.8-3.77 $\mathrm{mg} / \mathrm{l}$ whereas samples from battery showed the range of 1.54-3.97 mg/l. One finding was reported in which adverse effects of cadmium on crop was investigated such as the effect of cadmium accumulation on wheat grains was reported and suggested that children are more prone to its toxic effects $^{24}$.

\section{Isolation and screening of potential isolates}

A total of twenty different strains were obtained depending upon their ability to grow in the presence of cadmium which were further subjected to pollution reduction ability and found that out of twenty, strain no. 1, 2, 4 and 18 has reduced $74 \%, 72 \%, 73 \%$ and $74 \%$ of $B O D$ values respectively. The percentage of COD values reduced was $78 \%, 76 \%, 77 \%$ and $79 \%$ respectively for above mentioned strains. The similar results were obtained for TDS and TSS values, mentioned strains have reduced $45 \%, 43 \%, 49 \%$ and $52 \%$ of TDS and $69 \%, 72 \%, 68 \%$ and $69 \%$ of TSS respectively. Cadmium concentration was significantly reduced to $69 \%, 72 \%, 70 \%$ and $70 \%$ respectively. Furthermore, these strains were tested for their cadmium tolerance ability and found that ECd004 and SCd005 has ability to tolerate upto 1000 ppm and $1500 \mathrm{ppm}$ of cadmium concentration and selected for further study. Thus, it is evident that selected strains have good removal efficiency of cadmium, making bioremediation a good choice for removal of toxic pollutants from environment. 


\section{Biochemical and Molecular characterization}

ECd004 showed its positive response for Catalase, VP test, urease test, oxidase test, casein hydrolysis test, butyrate disk test, acetate utilization test, lecithinase and litmus test and negative result for coagulase, indole, citrate, as well as methyl red, starch hydrolysis, $\mathrm{H} 2 \mathrm{~S}$ production test and DNase test. In contrast, the strain SCd005 showed its positive result for urease, indole, starch hydrolysis test, casein hydrolysis test, acetate utilization test and litmus test whereas negative result for lecithinase, catalase, citrate, coagulase,
VP, MR, oxidase test, H2S production, gelatin hydrolysis test and DNase test.

The strain ECd004 belongs to Bacillaceae Family, Bacillales Order, Bacilli Class, Firmicutes Phylum, showed $95 \%$ identity with the strain Bacillus cereus CCM 2010 when BLAST was performed. The generic characters of strain ECd004 showed similarity with those of Bacillus cereus with high bootstrap value of confidence. The strain Sd0005 belongs to Class Proteobacteria Phyllum Betaproteobacteria, Order Burkholderiales and Family Burkholderiaceae,

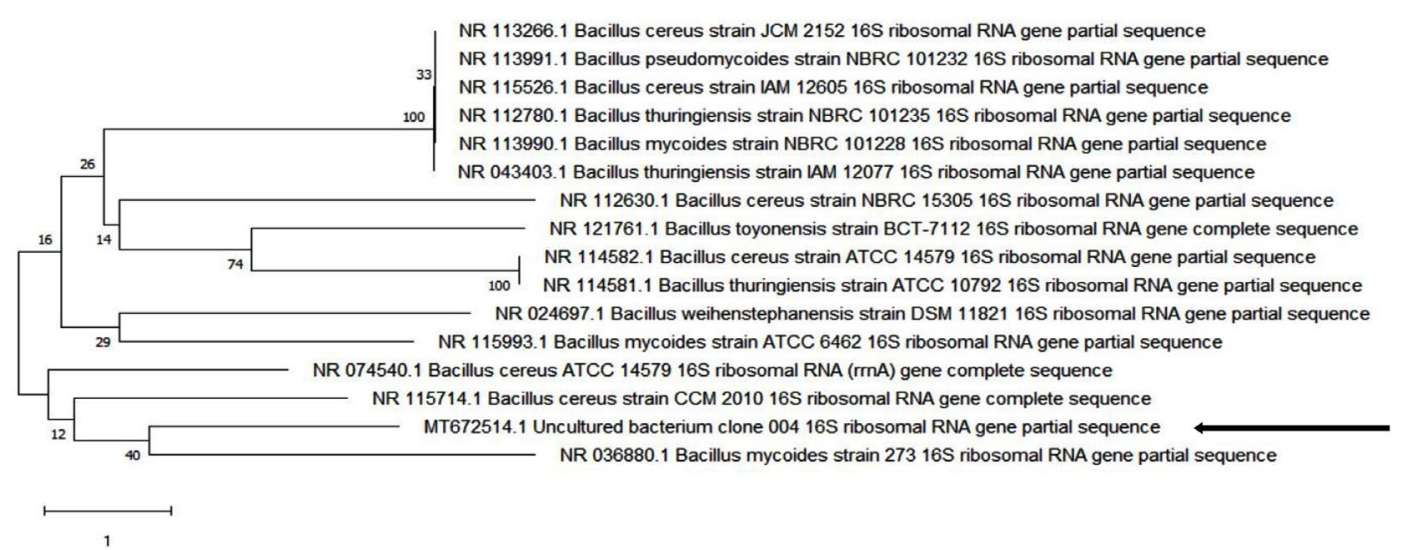

Fig. 1 (a). Phylogenetic tree for ECd004. The scale bar indicates 1 change per nucleotideposition (evolutionary distance).

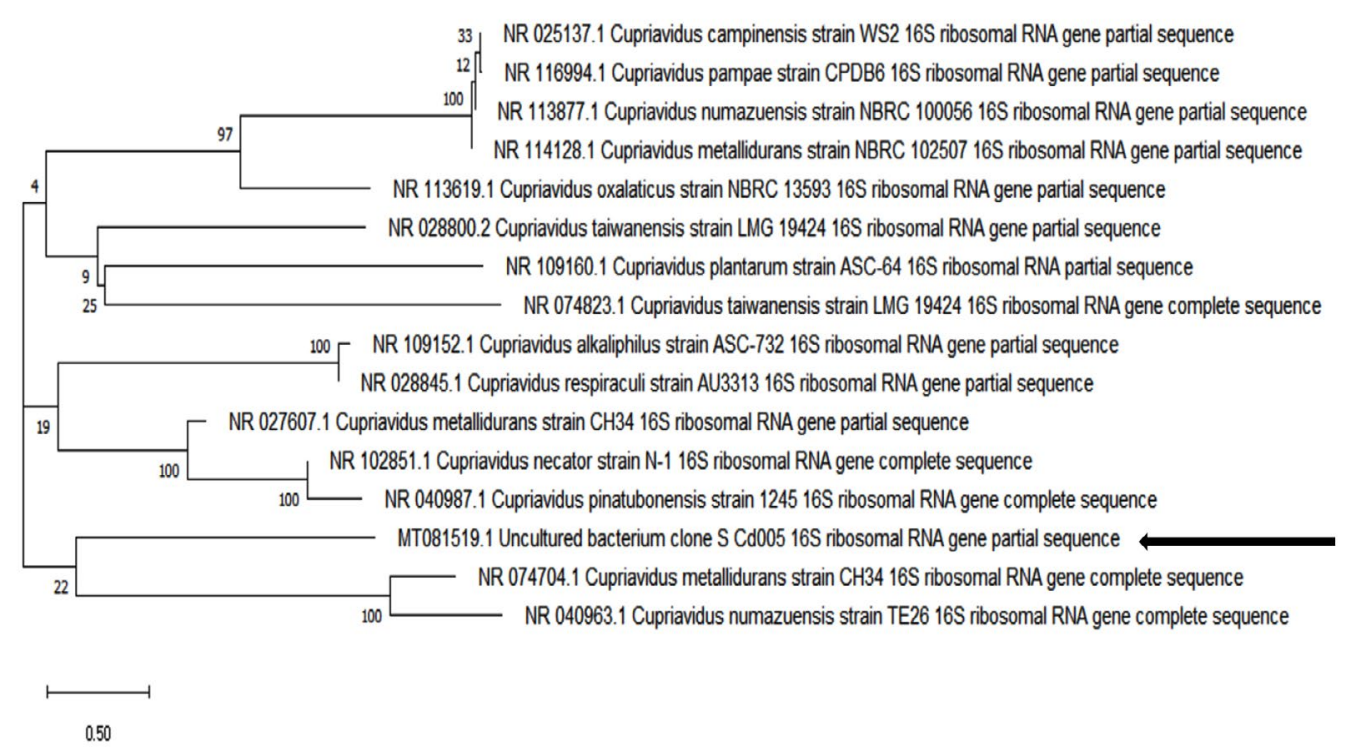

Fig. 1(b). Phylogenetic tree for SCd005.The scale bar indicates 0.5 changes per nucleotide position (evolutionary distance). 
Genus: Cupriavidus, showed $98 \%$ identity with the strain Cuprividus plantarum ASC 64 ( as per BLAST). Phylogenetic analysis of strains is shown in Fig. 1(a) and 1(b) The accession numbers were obtained by submitting the sequences in GenBank MT672514 and MT081519 for ECd004 and SCd005 respectively. Whole genome studies of Cupriavidus sp. HMR-1 isolated from waste water proves it to be having resistance towards multiple heavy metals especially cadmium ${ }^{25}$. Additionally, one more finding of Cupriavidus compinesis S14E4C exhibited its ability to tolerate cadmium upto $19.5 \mathrm{mM}^{26}$. Genomic screening of Bacillus cereus NWUAB01 revealed that it can tolerate $200 \mathrm{mg} / \mathrm{L}$ of $\mathrm{Cd}^{27}$.

Study of biosorption potential using Scanning electron microscopy and AAS

Scanning electron microscopy is widely used to observe changes in cell growth patterns (size and shape). The change in cell size and shape of Bacillus sp. (ECd004) and Cuprividus sp. (SCd005) was studied by using SEM. The results in Fig. 2 (a) and 1 (b) showed that the size of bacterial strains have increased which is the clear evidence of biosorption of cadmium in the bacterial cells. Similar finding was reported by Vicentin et al. ${ }^{28}$ in which the growth pattern of Cupriavidus necator was observed in the absence and presence of cadmium by using SEM and found that no exopolysaccharide production is responsible for cadmium biosorption. In another study by Khan et al. ${ }^{18}$ the tremendous increase in size of Salmonella enterica 43C, isolated from industrial effluent was observed and confirmed the biosorption of cadmium within the bacterial cells. In a finding reported by Zolgharnein, et al. ${ }^{29}$

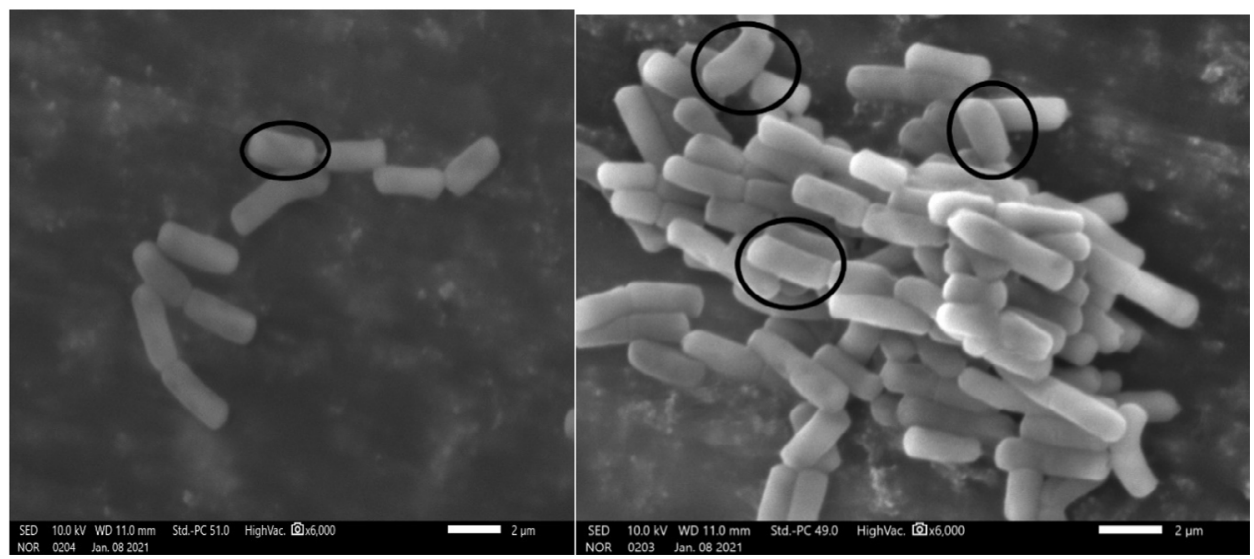

(a)

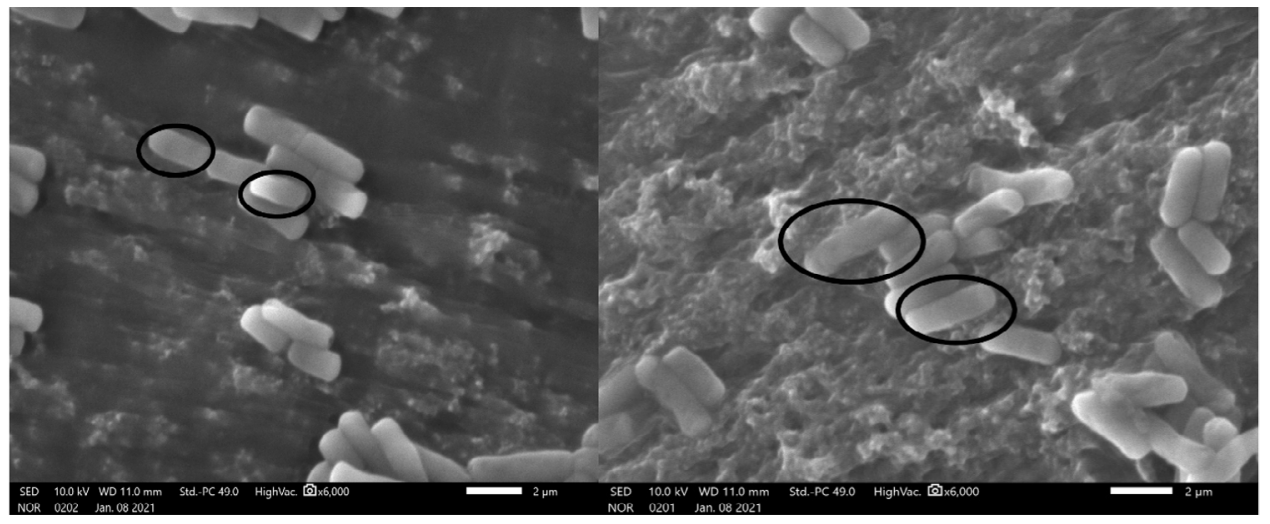

(b)

Fig. 2. Scanning electron microscopic images of a) ECd004 (b) SCd005 (Absence and presence of cadmium). 
clumping of cells of $P$. aeruginosa strain $\mathrm{MCCB}$ 102 was observed under SEM after the adsorption of the cadmium. The aggregation of cells was also reported in cadmium treated Lactobacillus plantarum MF042018, confirming the deposits of cadmium on surface of cells ${ }^{30}$. Like all these studies, clumping of cells were reported in ECd004 and SCd005 which is due to the biosorption and toxicity of cadmium internally. The binding of $\mathrm{Cd}$ with bacterium is guided by various moieties such as carboxyl, amino and phosphate.

Biosorption studies using atomic absorption Spectroscopy

Cadmium Biosorption of live bacterial isolates

Cadmium biosorption efficiency (E) of Bacillus sp. ECd004 was 0.5, 0.9, 1.20 and $1.65 \mathrm{mg} / \mathrm{l}$ after 2, 4, 6 and 8 days. For Cuprividus sp. SCd005 it was $0.4,0.7,1$ and $1.51 \mathrm{mg} / \mathrm{l}$ after 2, 4, 6 and
8 days of incubation respectively. The amount of cadmium found within Bacillus sp. after incubation of $2,4,6$ and 8 days was $0.4,0.75,0.92$ and 1.21 $\mathrm{mg} / \mathrm{l}$, respectively. While $0.12,0.2,0.37$ and 0.44 $\mathrm{mg} / \mathrm{l}$ of cadmium was found to be adsorbed on the bacterial surface after incubation of 2, 4, 6 and 8 days, respectively. For Cuprividus sp. the cadmium found within the cells was $0.28,0.56,0.86$ and 1.28 $\mathrm{mg} / \mathrm{l}$ and cadmium adsorbed on the surface was $0.18,0.20,0.14$ and $0.22 \mathrm{mg} / \mathrm{l}$ after incubation of 2, 4, 6 and 8 days of incubation Fig. 3(a) and 3(b). The results were in close pattern with one study on cadmium uptake by Salmonella enterica $43 \mathrm{C}$ which was isolated from industrial effluent, exhibit $83.4 \%$ of cadmium removal efficiency ${ }^{18}$. Free Cells of Klebsiella sp. isolated from wastewater were observed for their cadmium removal efficiency which was $170 \mathrm{mg} / \mathrm{g}$ of cadmium ${ }^{31}$.

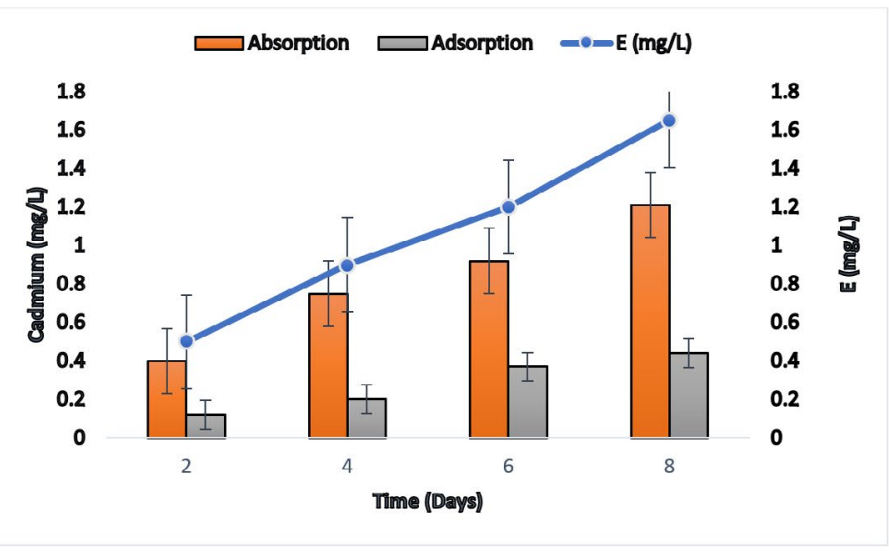

(a)

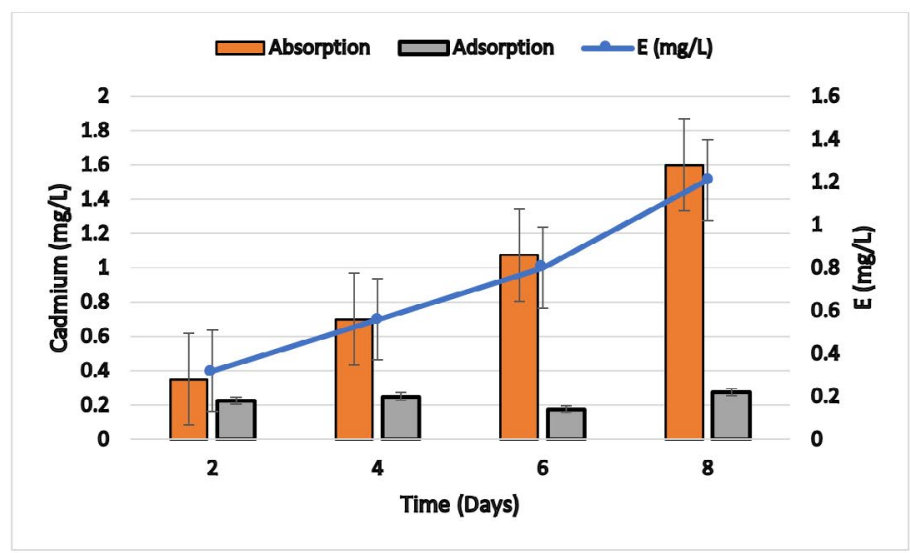

(b)

Fig. 3. Biosorption capability of a) Bacillus sp.ECd004 b) Cuprividus sp. SCd005 growing in culture medium supplemented with $2 \mathrm{mg} / \mathrm{l}$ of Cadmium. 


\section{Removal of Cadmium by heat inactivated bacterial cells}

Heat inactivated cells of Bacillus sp. ECd004 were observed removing 0.54,0.72,1.02 and $1.34 \mathrm{mg} / \mathrm{l}$ cadmium from aqueous medium, out of which $0.24,0.31,0.42$ and $0.52 \mathrm{mg} / \mathrm{l}$ cadmium was detected adsorbed on outer surface whereas $0.30,0.42,0.56$ and $0.79 \mathrm{mg} / \mathrm{l}$ cadmium was found accumulated within the cells after 2 , 4, 6 and 8 days, respectively and heat inactivated cells of Cuprividus sp. SCd005 were observed removing $0.34,0.74,1$ and $1.12 \mathrm{mg} / \mathrm{l}$ cadmium from aqueous medium, out of which $0.12,0.29,0.31$ and $0.34 \mathrm{mg} / \mathrm{l}$ cadmium was detected adsorbed on outer surface whereas $0.24,0.56,0.72$ and $0.78 \mathrm{mg} / \mathrm{l}$ cadmium was found accumulated within the cells after 2, 4, 6 and 8 days, respectively. The results are shown in Fig. 4(a) and 4 (b). The results were in close pattern with one study in which Salmonella enterica $43 \mathrm{C}$ was isolated from industrial effluent, exhibited good adsorption of cadmium on surface ${ }^{18}$. Thermal inactivated cells of $P$. agglomerans were investigated for removal of cadmium and found that its rate of removal was well comparable with live cells ${ }^{32}$. In another finding heat inactivated forms of Lentinus edodes biosorption capacity of $57.7 \pm 1.1 \mathrm{mg} / \mathrm{g}$ was noted ${ }^{33}$. Thus, species performed well even in inactivated state which proves their potential to remove cadmium either by accumulation or adsorption on the surface.

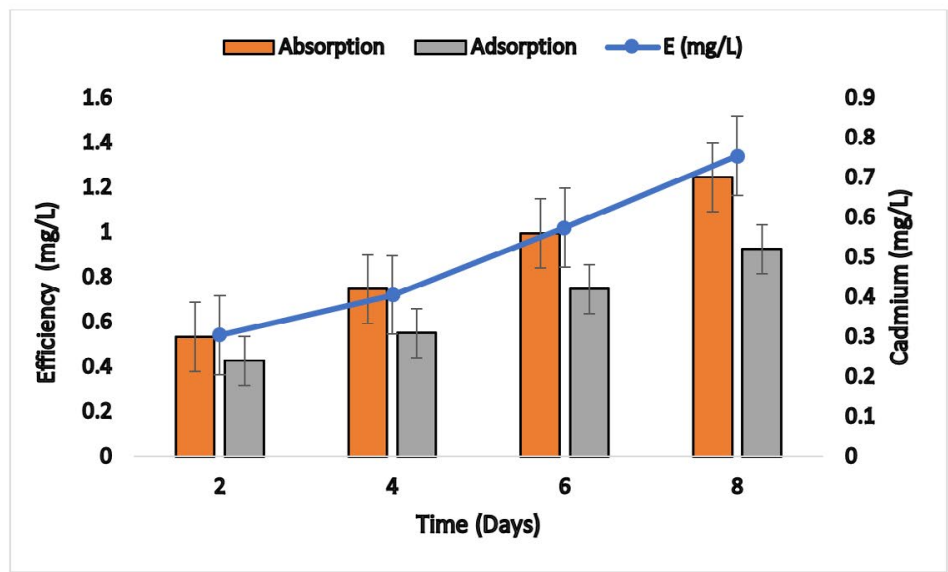

(a)

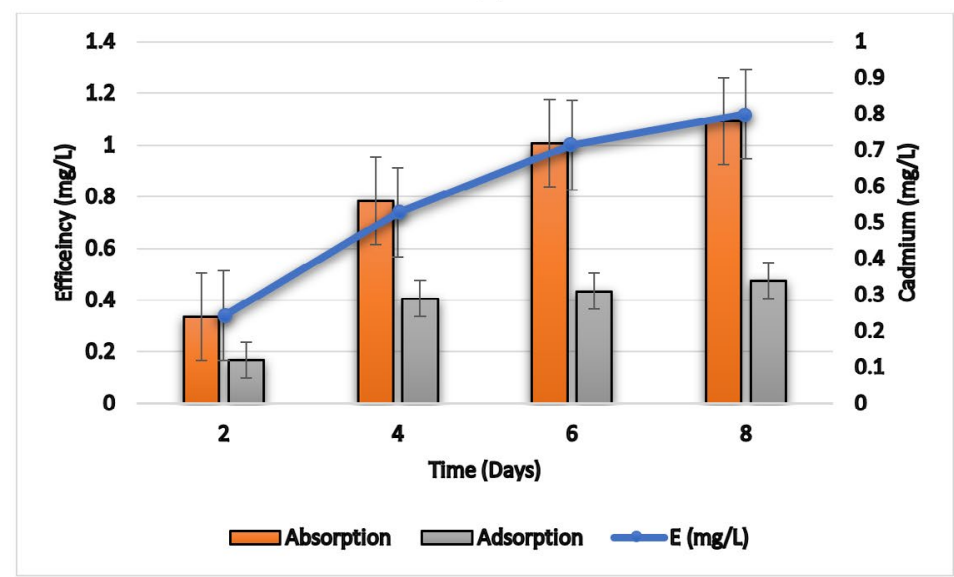

(b)

Fig. 4. Biosorption of Cd by using heat inactivated cells of a) Bacillus sp. ECd004 , b) Cuprividus sp.SCd005. 


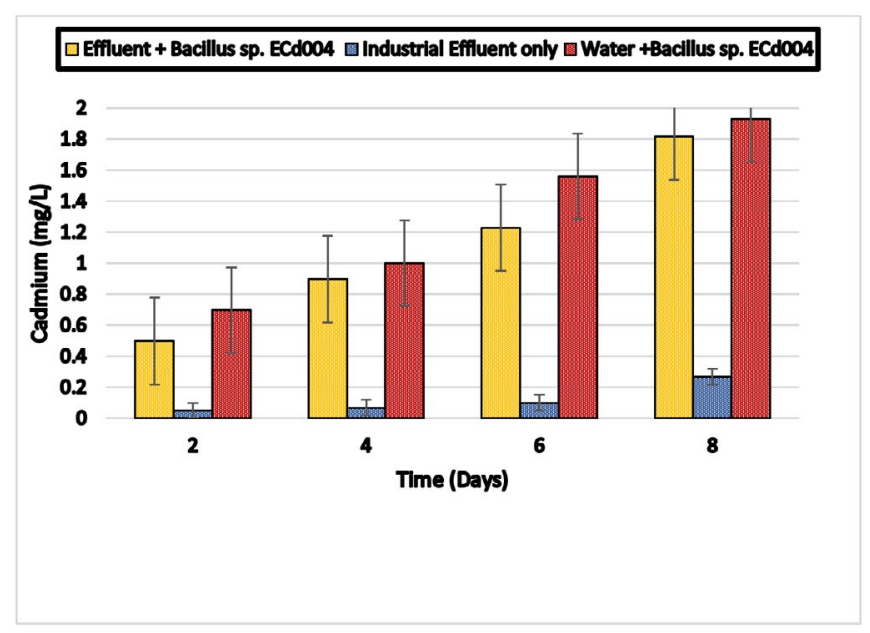

(a)

口Effluent + Bacillus sp. ECd004 DIndustrial Effiluent only —Water +Bacillus sp. ECd004

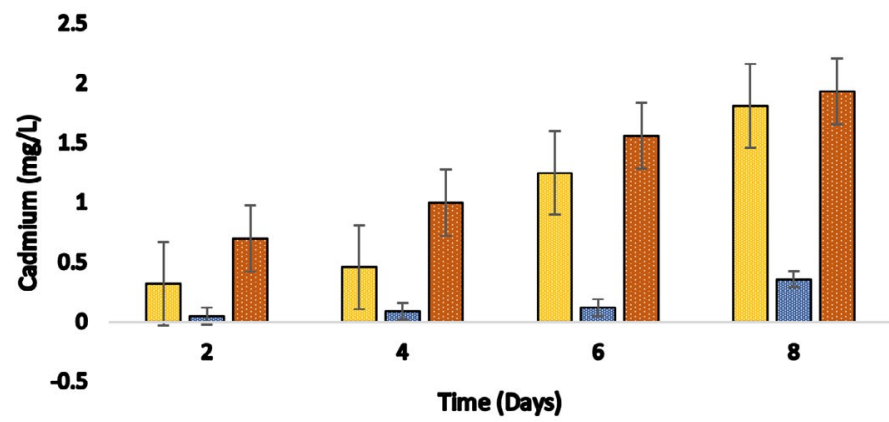

(b)

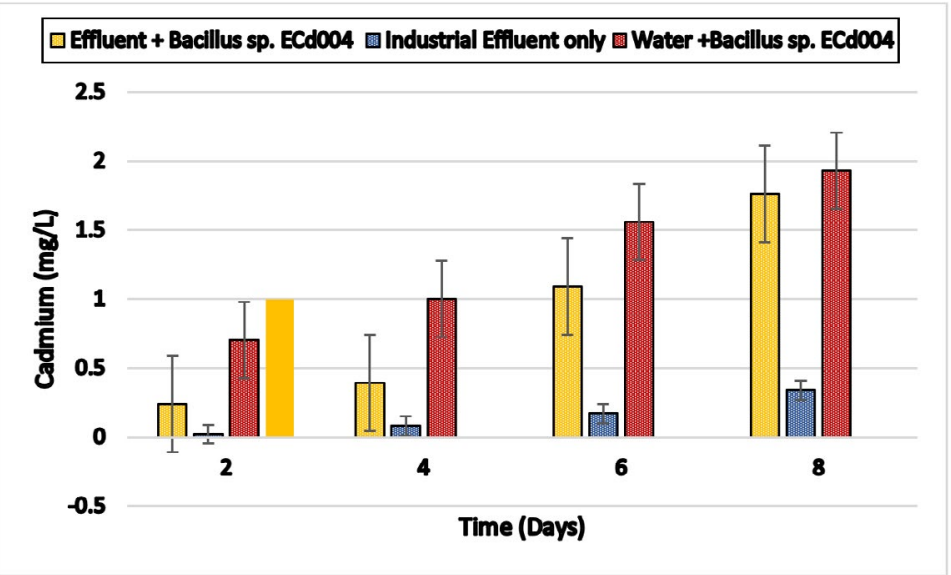

(c)

Fig. 5. Biosorption of Cadmium by a) Bacillus sp. ECd004 (Electroplating) b) Bacillus sp. ECd004 (Battery) c) Bacillus sp. ECd004 (Steel). 


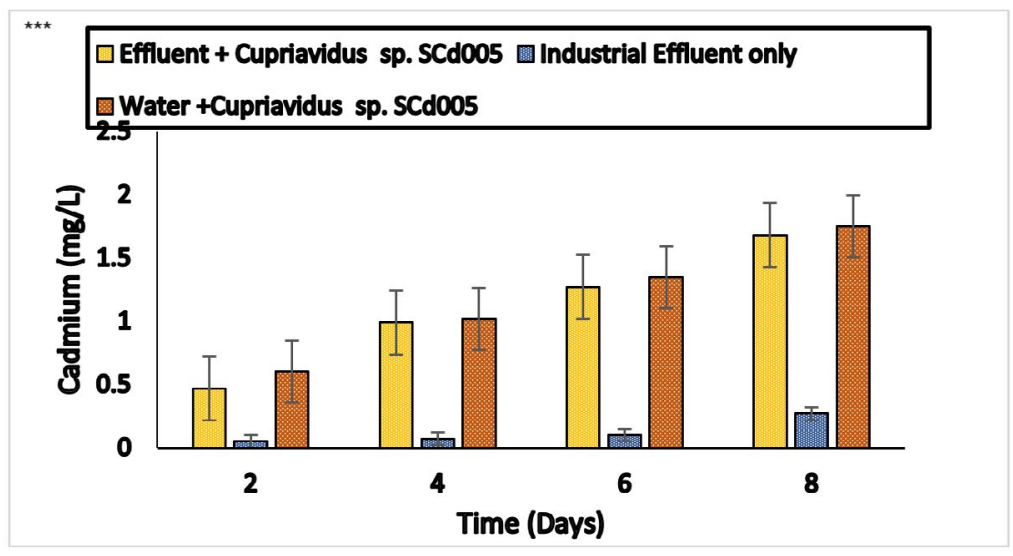

(a)

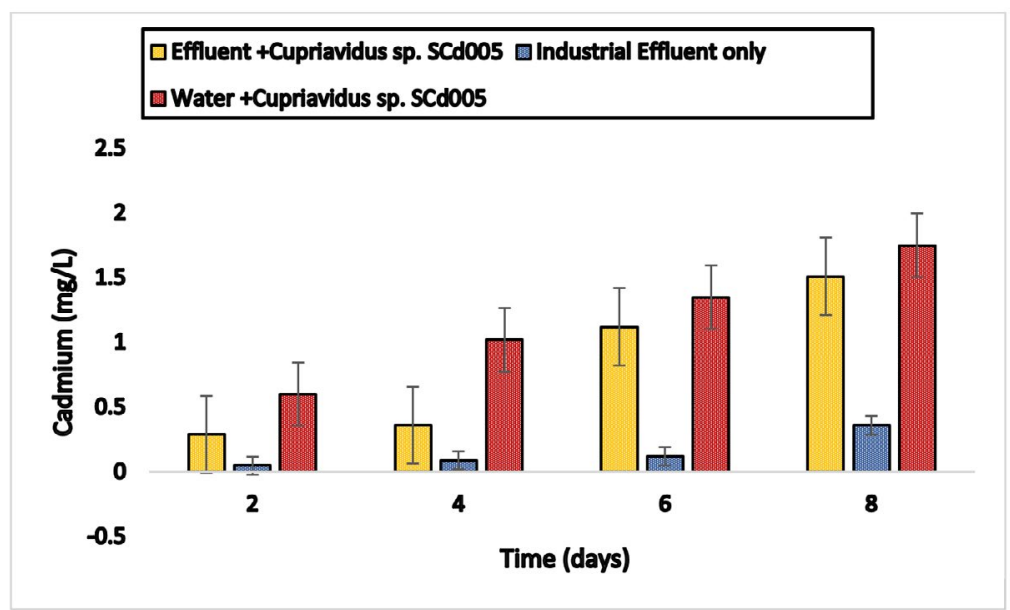

(b)

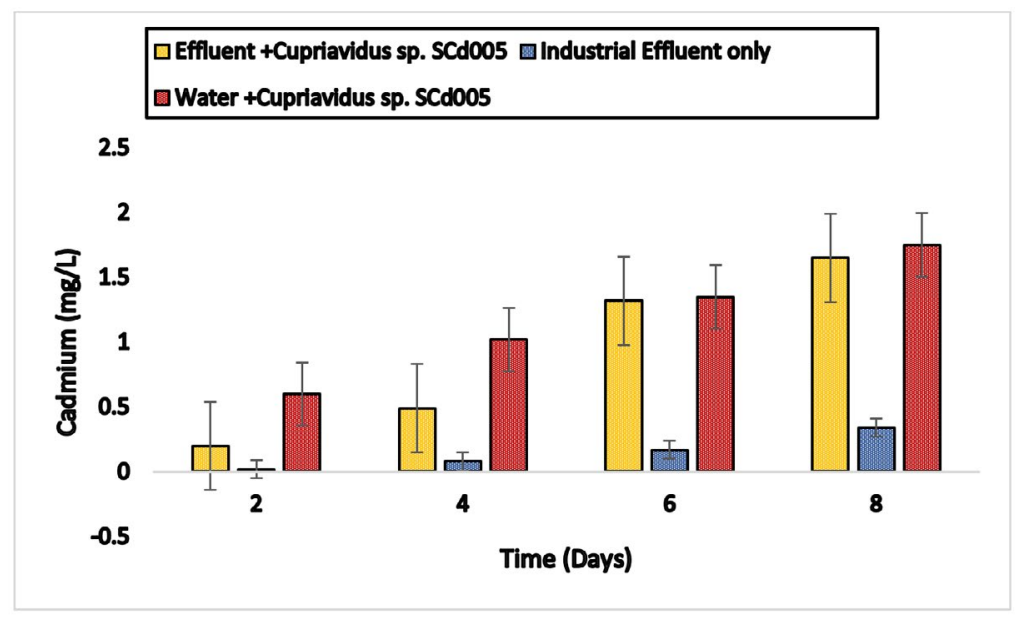

(c)

Fig. 6. Biosorption of Cadmium by a) Cupriavidus sp. SCd005 (Electroplating) b) Cupriavidus sp. SCd005 (Battery) c) Cuprividus sp. SCd005 (Steel).

Journal of Pure and Applied Microbiology 


\section{Cadmium removal from industrial effluents}

The cadmium concentration in electroplating, battery and steel wastewater was $2.12,1.97$ and $2.01 \mathrm{mg} / \mathrm{l}$. At industrial level, Bacillus sp. ECd004 was able to remove $0.5,0.9,1.23$ and $1.82 \mathrm{mg} / \mathrm{l}(90.2 \%)$ of cadmium from electroplating effluent and $0.32,0.46,1.25$ and $1.81 \mathrm{mg} / \mathrm{l}$ of cadmium from battery effluent as well as $0.24,0.39,1.09,1.76 \mathrm{mg} / \mathrm{l}$ of cadmium from steel industry wastewater after 2, 4, 6 and 8 days, respectively. Also $0.7,1,1.56$ and $1.93 \mathrm{mg} / \mathrm{l}$ from distilled water after incubation of 2, 4, 6 and 8 days, respectively. The results are shown in Fig. 5 (a), 5 (b) and 5 (c).

Cuprividus sp. SCd005 was able to remove $0.47,0.99,1.27$ and $1.68 \mathrm{mg} / \mathrm{l}$ of cadmium (87\%) from electroplating wastewater and 0.29,0.36,1.12 and $1.51 \mathrm{mg} / \mathrm{l}$ of cadmium from battery effluent as well as $0.20,0.49,1.32,1.65 \mathrm{mg} / \mathrm{l}$ of cadmium from steel industry wastewater after 2, 4, 6 and 8 days, respectively. Also $0.6,1.02,1.35$ and $1.75 \mathrm{mg} / \mathrm{l}$ from distilled water after incubation of 2, 4, 6 and 8 days, respectively. In 3rd container, there was only industrial wastewater. The microorganisms present naturally in electroplating wastewater was able to remove $0.03,0.07,0.1$ and $0.27 \mathrm{mg} / \mathrm{l}$ and in battery and steel wastewater, $0.05,0.09,0.12,0.36$ $\mathrm{mg} / \mathrm{l}$ and $0.02,0.08,0.17,0.34 \mathrm{mg} / \mathrm{l}$ after $2,4,6$ and 8 days, respectively. The results are shown in Fig. 6 (a), 6 (b) and 6 (c).

\section{Effect of bioformulations on germination rate} of seed

The effect of bioformulations was checked on germination ability of Vigna radiata and Cicer arietinum seeds. The seeds were grown in all three industry soil samples i.e., electroplating, battery and steel. The positive control (seeds grown in normal garden soil) was taken. The seed germination rate of positive control was compared with negative control (Seeds grown in industry soil) and bioformulations (Seeds grown in industry soil but treated with bioformulations). It is clear from the Fig. 7 (a), 7 (b) and 7 (c) that the prepared bioformulations are competent for enhancing the germination rate in seeds.

The Vigna radiata seed germination rate (in soil of electroplating industry) in positive control was $90 \%$, in negative control it was $25 \%$ whereas the seed treated with bioformulations have shown the rate of $76 \%$ and $72 \%$. Similar

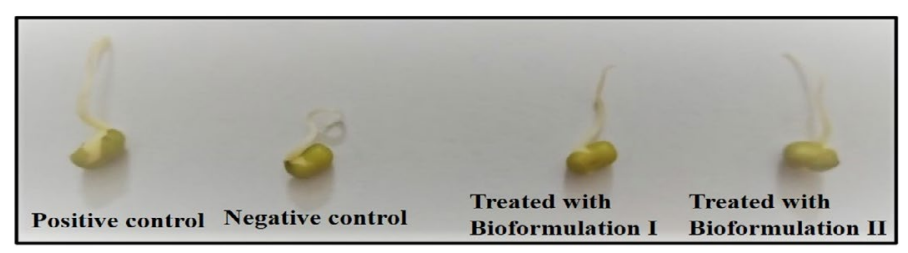

(a)

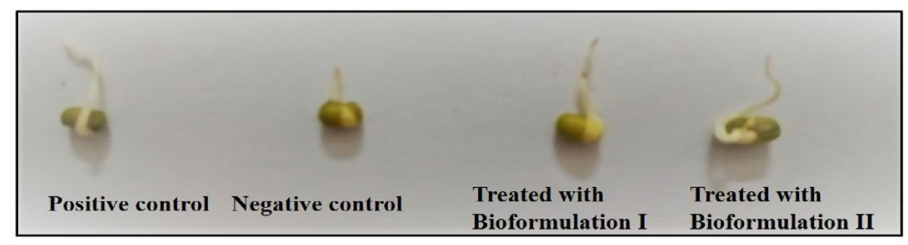

(b)

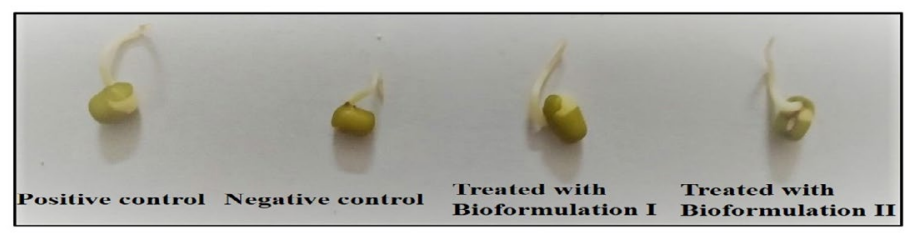

(c)

Fig. 7. Seed germination rate of Vigna radiata in samples of a) Electroplating industry b) Battery industry c) Steel industry 
results were obtained in seeds grown in battery and steel industry soil in which positive control was $87 \%$ and $89 \%$, the negative control was $25 \%$ and $22 \%$ whereas with bioformulation I it was $72 \%$ and $69 \%$ and with bioformulation II, the rate was $68 \%$ and $72 \%$. The results obtained were significant (ANOVA $\mathrm{p}<0.0001$ ).

The experiment was also done with seeds of Cicer arietinum in which seed germination rate (in soil of electroplating industry) in positive control was $82 \%$, in negative control it was $32 \%$ whereas the seed treated with bioformulations have shown the rate of $79 \%$ and $74 \%$. Similar results were obtained in seeds grown in battery and steel industry soil in which positive control was $80 \%$ and $85 \%$, the negative control was $35 \%$ and $36 \%$ whereas with bioformulation I it was $72 \%$ and $68 \%$ and with bioformulation II, the rate was $70 \%$ and $64 \%$. The results obtained were significant (ANOVA, $\mathrm{p}<0.0001$ ). The results are shown in Fig. 8 (a), 8 (b) and 8 (c). Similar finding was reported by Neddy et al. ${ }^{34}$ in which Pseudomonas aeruginosa KP717554 showed the improvement in germination rate of seeds of $B$. juncea in the presence of cadmium. Additionally, Serratia marcescens S2I7 was investigated for its plant growth promoting properties and found that the growth of rice seedling was increased with respect to its shoot as well as root length, also it showed the decrease in residual amount of $\mathrm{Cd}$ in soil when plants were grown in contaminated soil ${ }^{35}$. Thus, the present study reports that the isolated strains have ability to enhance seed germination rate in cadmium toxic conditions

\section{Effect of Bioformulations on the growth of seedlings}

The parameters such as root as well shoot length were taken in account for checking the impact of bioformulations on seedlings growth. Both $V$. radiata and $C$. arietinum were studied for the same. Shoot length of Vigna radiata seeds grown in electroplating industry soil samples was $13 \mathrm{~cm}$ in positive control and was $6 \mathrm{~cm}$ in negative control, whereas it was $12 \mathrm{~cm}$ and $11 \mathrm{~cm}$ with

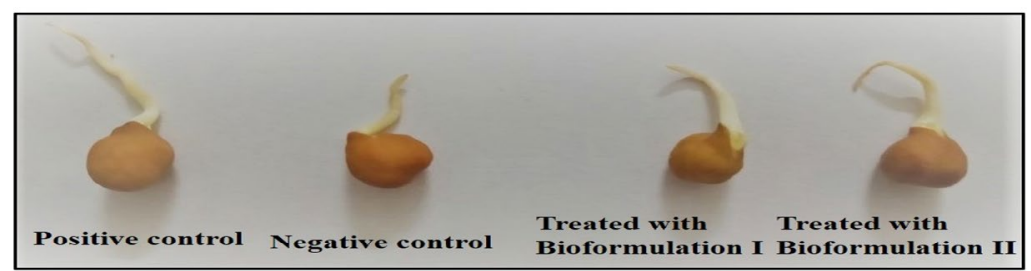

(a)

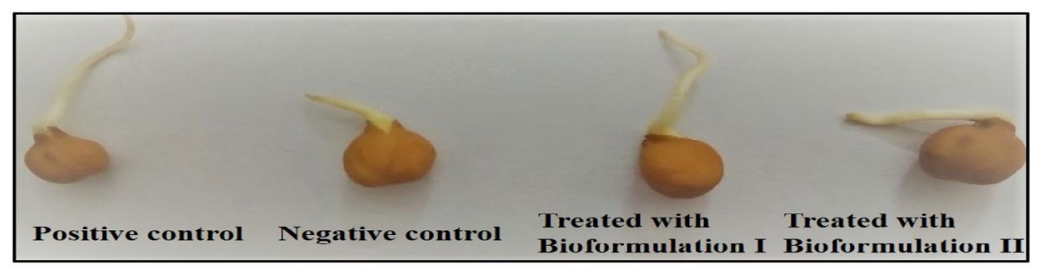

(b)

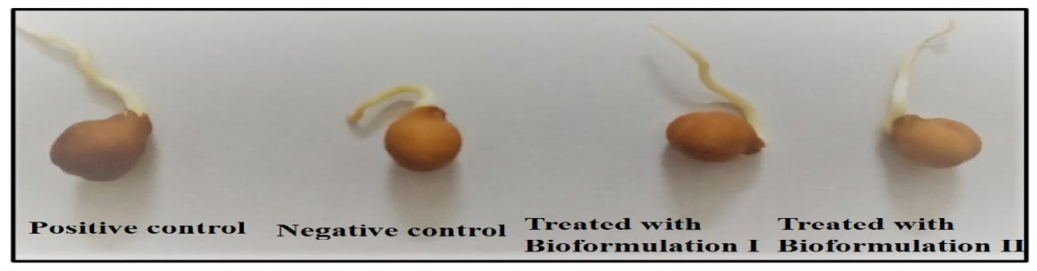

(c)

Fig. 8. Seed germination rate of Cicer arietinum in samples of a) Electroplating industry b) Battery industry c) Steel industry. 
bioformulations. The result is shown in Fig. 9 (a). Similar results were observed in seedlings grown in soil of battery and steel industry in which shoot length was $13 \mathrm{~cm}$ in positive control and was $8 \mathrm{~cm}$ and $5 \mathrm{~cm}$ in negative control, whereas it was 12 $\mathrm{cm}$ and $11.5 \mathrm{~cm}$ with bioformulation I and $10 \mathrm{~cm}$ and $9.5 \mathrm{~cm}$ with bioformulation II. The root length showed the tremendous increase in size in Vigna radiata plants. With both of the formulations the root length $(1.7 \mathrm{~cm}$ and $1.6 \mathrm{~cm}$ in electroplating industry soil) was as compatible as it was in positive control $(2 \mathrm{~cm})$. The results are shown in Fig. 9 (b) and 9 (c).

The seedlings grown in battery and steel industry soil also showed the similar results, the positive control was $2 \mathrm{~cm}$ and the root length with bioformulation I was $1.5 \mathrm{~cm}$ and $1.4 \mathrm{~cm}$ and with bioformulation II it was $1.4 \mathrm{~cm}$ and $1.2 \mathrm{~cm}$. The results were in close pattern with a study in which effect on growth of tomato plants was checked by using cadmium resistant Enterobacter sp. EG16 and Enterobacte rludwigii $\mathrm{DJ}^{36}$. In another finding Providencia sp., Morganella sp., Stenotrophomonas sp., and Bacillus sp. were studied for their effect on plant growth and uptake of cadmium by roots of Sesbania bispinosa ${ }^{37}$. The bacterial strain Klebsiella pneumoniae MCC 3091 was studied for promoting the growth of rice seedling growth by lessening the phytotoxicity of cadmium $^{38}$

The Cicer arietinum plants were grown in all the three selected soil samples. Root length was more (ranging from $1.9 \mathrm{~cm}-2.1 \mathrm{~cm}$ ) than the negative control (ranges from $0.9 \mathrm{~cm}-1 \mathrm{~cm}$ ). Shoot length in positive control was $8.5 \mathrm{~cm}$ and with bioformulations it ranges from $5.6-8 \mathrm{~cm}$. The results are shown in Fig. 10 (a), 10 (b) and 10 (c).

The results obtained were significant (ANOVA, $p<0.0001$ ). The results were in close pattern with a study in which, Rhodococcus sp.Variovorax paradoxus and Flavobacterium sp. were isolated from roots of Indian mustard and were studied for stimulating the elongation of roots of $B$. juncea seedlings ${ }^{39}$. In another report

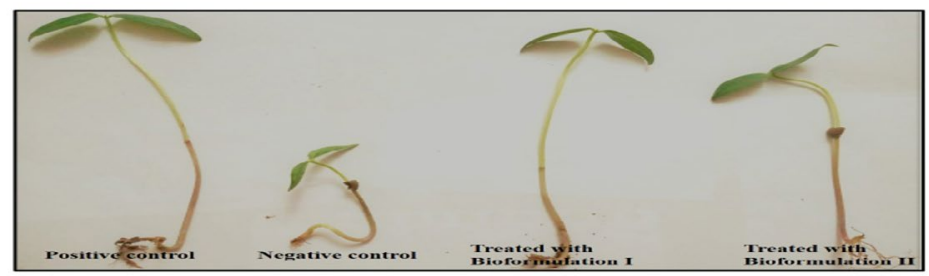

(a)

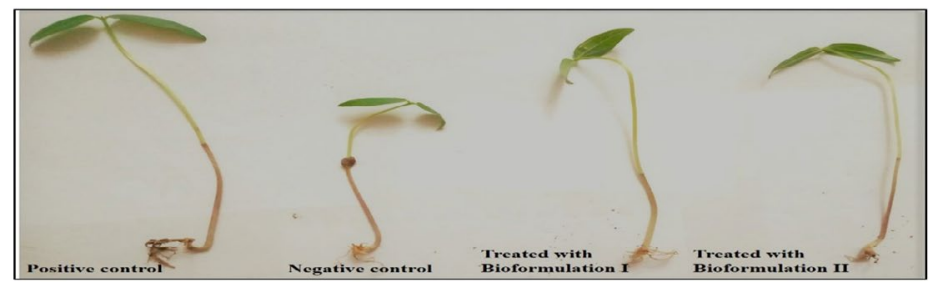

(b)

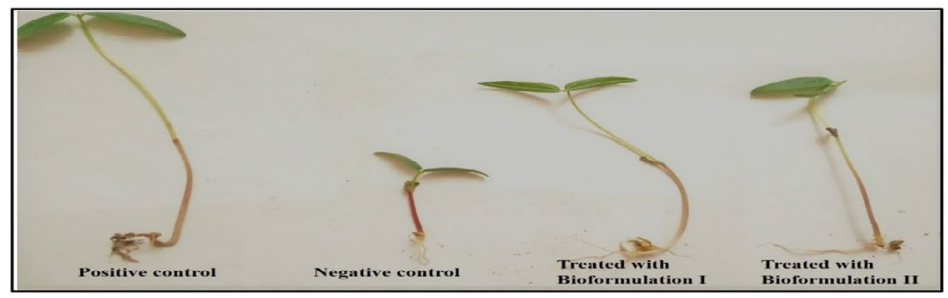

(c)

Fig. 9. Plant Growth of Vigna radiata in samples of a) Electroplating industry b) Battery industry c) Steel industry. 


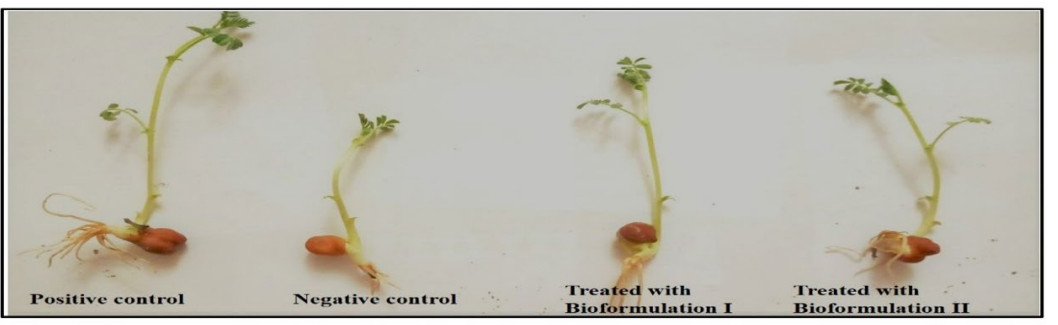

(a)

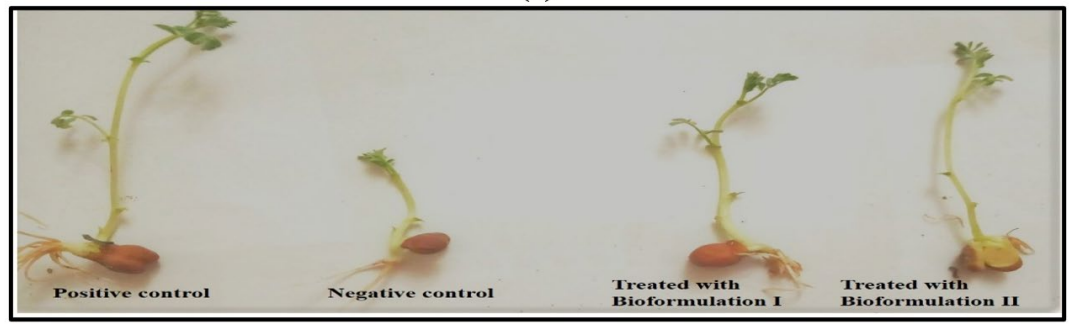

(b)

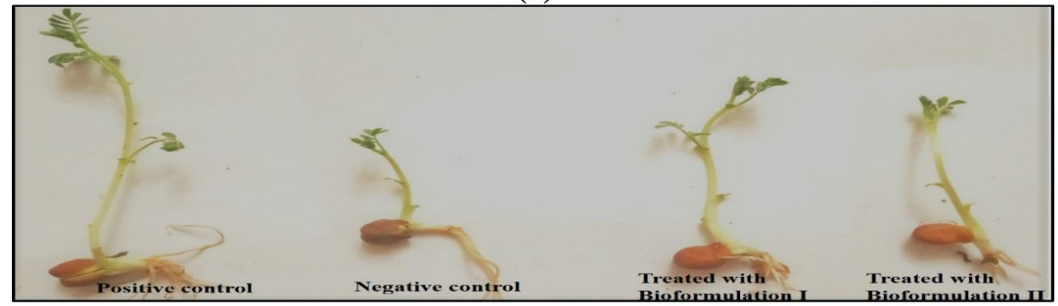

(c)

Fig. 10. Plant Growth of Cicer arietinum in samples of a) Electroplating industry b) Battery industry c) Steel industry.

by Safronova et al. ${ }^{40}$ the effect of Pseudomonas brassica cearum AM3 on growth of shoots of Pisum sativum was studied and observed that all the strains enhanced the root growth and nutrient uptake processes. In another finding Enterobacter sp. CR 191, Enterobacter sp. CR20I and Arthrobacter sp. TM6 were recognised as IAA-producing bacteria which have enhanced the root elongation of Ocimum gratissimum under cadmium noxious conditions ${ }^{41}$. The present observations revealed that the inhibitory and toxic effects of cadmium is overpowered by $\mathrm{Cd}$ resistant strains by increasing mobilization of cadmium in contaminated soil to protect the plants probably owing to exhibition of plant growth promoting properties.

\section{CONCLUSIONS}

In the present investigation, Bacillus sp. and Cupriavidus sp. were screened for cadmium resistance with $87 \%$ and $90 \%$ of cadmium biosorption potentiality respectively and electron micrographs also revealed the increase in size of bacterial cells due to significant absorption of cadmium in them. Furthermore, strains were evaluated for their remediation potential by assessing differences in seed germination rate and seedlings growth parameters. The remarkable finding of supplementing the seedlings growth proves them as the potential isolates of cadmium remediation. Thus, the strains have obvious favourable effects as they significantly reduced high cadmium concentration and their implementation offers an economical and ecofriendly approach for remediation of cadmium contaminated soils for sustainability of agriculture. Future studies of their molecular aspects can make them suitable isolates for restoration of cadmium contaminated areas.

\section{ACKNOWLEDGMENTS}

Authors are grateful to University Institute of Biotechnology, Chandigarh University, 
Gharuan for providing platform for research and valuable guidance.

\section{CONFLICT OF INTEREST}

The authors declares that there is no conflict of interest.

\section{AUTHORS' CONTRIBUTION}

All authors listed have made a substantial, direct and intellectual contribution to the work, and approved it for publication.

\section{FUNDING}

The study was supported in terms of infrastructure, instrumentation and chemicals by Chandigarh University, Gharuan.

\section{DATA AVAILABILITY}

All datasets generated or analyzed during this study are included in the manuscript.

\section{ETHICS STATEMENT}

Not applicable.

\section{REFERENCES}

1. Zaki S, Farag S. Isolation and molecular characterization of some copper biosorped strains. Int J Environ Sci Techno. 2010;7(3):553-560. doi: 10.1007/BF03326164

2. Banjerdkij P, Vattanaviboon P, Mongkolsuk S. Exposure to cadmium elevates expression of genes in the oxyr and ohrrregulons and induces cross-resistance to peroxide killing treatment in Xanthomonas campestris. Appl Environ Microbiol. 2005;71(4):1843-1849. doi: 10.1128/AEM.71.4.1843-1849.2005

3. Joseph P. Mechanisms of cadmium carcinogenesis. Toxicol Appl Pharmacol. 2009;238(3):272-279. doi: 10.1016/j.taap.2009.01.011

4. He M, Li X, Liu H, Miller SJ, Wang G, Rensing C. Characterization and genomic analysis of a highly chromate resistant and reducing bacterial strain Lysinibacillus fusiformis ZC1. J Hazard Mater. 2011;185(2-3):682-688. doi: 10.1016/j. jhazmat.2010.09.072

5. Mahvi AH, Diels L. Biological removal of cadmium by Alcaligenes eutrophus CH34. Int J Environ Sci Technol. 2004;1(3):199-204. doi: 10.1007/BF03325833

6. Li Z, Yuan H. Characterization of cadmium removal by Rhodotorula sp. Y11. Appl Microbiol Biotechnol. 2006;73(2):458-463. doi: 10.1007/s00253-006-0473-8

7. Ziagova M, Dimitriadis G, Aslanidou D, Papaioannou X, Tzannetaki EL, Liakopoulou-Kyriakides M. Comparative study of Cd (II) and $\mathrm{Cr}$ (VI) biosorption on Staphylococcus xylosus And Pseudomonas sp. in single and binary mixtures. Bioresour Technol. 2007;98(15):2859-2865. doi: 10.1016/j.biortech.2006.09.043

8. Sinha S, Mukherjee SK. Pseudomonas aeruginosa
KUCd1, a possible Candidate for cadmium bioremediation. Braz J Microbiol. 2009;40(3):655662. doi: 10.1590/S1517-83822009000300030

9. Brahmbhatt $\mathrm{NH}$, Patel VR, Jasraj RT. Bioremediation potential of Spirogyra sp. and Oscillatoria sp. for cadmium. Asian J Pharm. 2012;2(2):102-107.

10. Yasmeen T, Ali Q, Islam F, Noman A, Akram MS, Javed MT. Biologically treated Waste water fertigation induced growth and yield enhancement effects in Vigna radiata L. Agric Water Manag. 2014:146:124130. doi: 10.1016/j.agwat.2014.07.025

11. Keser G. Effects of irrigation with wastewater on the physiological properties and heavy metal content in Lepidium sativum L. and Eruca sativa (Mill). Environ Monit Assess. 2013;185(7):6209-6217. doi: 10.1007/ s10661-012-3018-x

12. American Public Health Association (APHA). Standard Methods for the examination of water and wastewater (18th edition),Washington, DC. 1992.

13. Ullah M, Haque ME. Spectrophotometric determination of toxic elements (Cadmium) in aqueous media. J Chem Eng. 2011;25:1-12. doi: 10.3329/jce.v25i0.7233

14. Marzan LW, Hossain M, Mina SA, Akter Y, Chowdhury AMMA. Isolation and biochemical characterization of heavy-metal resistant bacteria from tannery effluent in Chittagong city, Bangladesh: Bioremediation viewpoint. Egypt J Aquat Res. 2017;43(1):65-74. doi: 10.1016/j.ejar.2016.11.002

15. Krishnaswamy U, Muthusamy M, Perumalsamy L. Studies on the efficiency of the removal of phosphate using bacterial Consortium for the Bio treatment of Phosphate wastewater. Eur J Appl. 2009;1(1):06-15.

16. Bergey DH, Holt JG. Bergey's manual of determinative bacteriology. 9th edition. Philadelphia: Lippincott Williams \& Wilkins; 2000.

17. Fischer ER, Hansen BT, Nair V, Hoyt FH, Dorward DW. Scanning electron microscopy. Curr Protoc Microbiol. 2012;25(1):2B.2.1-2B.2.47. doi: 10.1002/9780471729259.mc02b02s25

18. Khan Z, Rehman A, Hussain SZ, Nisar MA, Zulfiqar $S$, Shakoori AR. Cadmium resistance and uptake by bacterium, Salmonella enterica 43C, isolated from industrial effluent. AMB Express. 2016;6(54):1-16. doi: 10.1186/s13568-016-0225-9

19. Billah $M$, Khan M, Bano A, Hassan TU, Munir A, Gurmani AR. Phosphorus and phosphate solubilizing bacteria: Keys for sustainable agriculture. Geo microbiol J. 2019;36(10):904-916. doi: 10.1080/01490451.2019.1654043

20. Prabhudesai HR. Use of Biofertilizers. Extension Folder No.17 ICAR Research Complex for Goa. 1998:1-6.

21. Nigeria. Ministry of Environment - FME. National guidelines and standards for water quality in Nigeria. Rishab Printing Press Production,2001:114. https:// health.gov.ng/doc/StandardWaterQuality.pdf

22. World Health Organization. A compendium of standards for wastewater reuse in the eastern Mediterranean region. World Health Organization (WHO) Regional Office for Eastern Mediterranean Regional Centre for Environmental Health Activities CEHA Los Angeles, CA, USA, 2006:1-19. https://apps. who.int/iris/handle/10665/116515 
23. Duinker JC, Nolting RF,Van der Sloot HA. The determination of suspended metals in coastal water by different sampling and processing techniques (filtration and centrifugation). Neth J Sea Res. 1979;13(2):282297. doi: 10.1016/0077-7579(79)90007-3

24. Asgari $\mathrm{K}$, Cornelis WM. Heavy metal accumulation in soils and grains, and health risks associated with use of treated municipal wastewater in subsurface drip irrigation. Environ Monit Assess. 2015;187(7):410. doi: 10.1007/s10661-015-4565-8

25. Li L-G, Cai L, Zhang T. Genome of Cupriavidus sp. HMR-1, a heavy metal-resistant bacterium. Genome Announc. 2013;1(1). doi: 10.1128/genomeA.00202-12

26. Abbaszade G, Szabo A, Vajna B, Farkas R, Szabo $C$, Toth $E$. Whole genome sequence analysis of Cupriavidus campinensis S14E4C, a heavy metal resistant bacterium. Mol Biol Rep. 2020;47(5):39733985. doi: 10.1007/s11033-020-05490-8

27. Ayangbenro AS, Babalola OO. Genomic analysis of Bacillus cereus NWUAB01 and its heavy metal removal from polluted soil. Sci Rep. 2020;10:19660. doi: 10.1038/s41598-020-75170-x

28. Vicentin RP, Santos JV, dos Labory CRG, Costa AM, da Moreira FM, Alves E. Tolerance to and accumulation of cadmium, copper, and zinc by Cupriavidus necator. Rev Bras Cienc Solo. 2018;42:1-12. doi: 10.1590/18069657rbcs20170080

29. Zolgharnei H, Karami K, Mazaheri AM, Dadolahi SA. Investigation of heavy metals biosorption on Pseudomonas aeruginosa Strain MCCB 102 isolated from the Persian Gulf. Asian J Biotechnol. 2010;2:99109. doi: 10.3923/ajbkr.2010.99.109

30. Ameen FA, Hamdan AM, El-Naggar MY. Assessment of the heavy metal bioremediation efficiency of the novel marine lactic acid bacterium Lactobacillus plantarum MF042018. Sci Reps. 2020;10:314. doi: 10.1038/ s41598-019-57210-3

31. Hou Y, Cheng K, Li Z, et al. Biosorption of cadmium and manganese using free cells of Klebsiella sp. isolated from waste water. PLOS ONE. 2015;10(10):e0140962. doi: 10.1371/journal.pone.0140962

32. Acioly LML, Cavalcanti D, Luna MC, et al. Cadmium removal from aqueous solutions by strain of Pantoea agglomerans UCP1320 isolated from laundry effluent. Open Microbiol J. 2018;12(1):297-307. doi: 10.2174/1874285801812010297

33. Bayramoglu G, Arıca MY. Removal of heavy mercury(II), cadmium(II) and zinc(II) metal ions by live and heat inactivated Lentinus edodes pellets. Chem Eng J. 2008;143(1-3):133-140.

34. Ndeddy Aka RJ, Babalola OO. Effect of bacterial inoculation of strains of Pseudomonas aeruginosa, Alcaligenes faecalis and Bacillus subtilis on germination, growth and heavy metal $(\mathrm{Cd}, \mathrm{Cr}$, and $\mathrm{Ni}$ ) uptake of Brassica juncea. Int J Phytoremediation. 2015;18(2):200209. doi: 10.1080/15226514.2015.1073671

35. Kotoky R, Nath S, Kumar Maheshwari D, Pandey P. Cadmium resistant plant growth promoting rhizobacteria Serratia marcescens S2I7 associated with the growth promotion of rice plant. J Environ Sustain. 2019;2(2):135-144. doi: 10.1007/s42398-019-00055-3

36. Li Y, Zeng J, Wang S, et al. Effects of cadmiumresistant plant growth-promoting rhizobacteria and Funneliformis mosseae on the cadmium tolerance of tomato (Lycopersicon esculentum L.). Int J Phytoremediation. 2020;22(5):451-458. doi: 10.1080/15226514.2019.1671796

37. Kartik VP, Jinal HN, Amaresan N. Characterization of cadmium-resistant bacteria for its potential in promoting plant growth and cadmium accumulation in Sesbania bispinosa root. Int $J$ Phytoremediation. 2016;18(11):1061-1066. doi: 10.1080/15226514.2016.1183576

38. Pramanik K, Mitra S, Sarkar A, Soren T, Maiti TK. Characterization of cadmium-resistant Klebsiella pneumoniae MCC 3091 promoted rice seedling growth by alleviating phytotoxicity of cadmium. Environ Sci Pollut Res Int. 2017;24(31):24419-24437. doi: 10.1007/ s11356-017-0033-z

39. Belimov AA, Hontzeas N, Safronova VI, et al. Cadmiumtolerant plant growth-promoting bacteria associated with the roots of Indian mustard (Brassica juncea $\mathrm{L}$. Czern.). Soil Biol Biochem. 2005;37(2):241-250. doi: 10.1016/j.soilbio.2004.07.033

40. Safronova VI, Stepanok VV, Engqvist GL, Alekseyev YV, Belimov AA. Root-associated bacteria containing 1-aminocyclopropane-1-carboxylate deaminase improve growth and nutrient uptake by pea genotypes cultivated in cadmium supplemented soil. Bio Fertil Soils. 2006;42(3):267-272. doi: 10.1007/s00374-0050024-y

41. Prapagdee B, Chumphonwong N, Khonsue N, Mongkolsuk S. Influence of cadmium resistant bacteria on promoting plant root elongation and increasing cadmium mobilization in contaminated soil. Fresenius Environ Bull. 2012;21:1186-1191. 